\title{
MODAL SOSIAL DAN PEMBANGUNAN KETAHANAN PANGAN BERKELANJUTAN
}

\section{SUSTAINABLE FOOD SECURITY DEVELOPMENT AND SOCIAL CAPITAL}

\author{
Suandi \\ Dosen Tetap pada Jurusan Agribisnis Fakultas Pertanian Universitas Jambi \\ Kampus Pinang Masak, Jln. Raya Jambi-Muara Bulian, Mendalo Darat KM. \\ 15 Jambi, 36361. Telepon: (0741) 583051, Fax: (0741) 583051 \\ E-mail:wandy_ipb@yahoo.com
}

\begin{abstract}
The purpose of the study are (1) Identify the various characteristics of household food security in rural areas, (2) Identify the social capital that developed in rural areas, (3) Identify the various characteristics of sustainable food security in rural areas and (4) Analysis of social capital on development of sustainable food security in various community groups. The study design was cross sectional. The study was conducted in Kerinci regency, by the time the research for 8 (eight) months of the calendar. Research variables: (1) family food security (availability, accessibility, and utilization of food and nutrition, (2) social capital (local associations and public characters), and (3) Sustainable food security (ecology, economic status, and sosio-demographic), with the number of respondents 165 households. The data were analyzed using models of Structural Equation Modelling (SEM) by LISREL program. The results showed: (1) the level of household food security in Kerinci regency good views of availability, accessibility and household utilization of nutrients obtained quite enough and stable. Respondents in the study area has a fairly high level of stability of food consumption (energy and protein consumption), (2) social capital in the study area owned by households is high and good views of the local association level as well as from the aspect of interaction and community character, (3) sustainable food security is enough high, (4) social capital (local associations and public characters) either directly or indirectly have a positive highly significant to the development of food security and sustainable food security. That is, the higher and varied levels of social capital owned by the family, the more stable the level of food security so that the turn can improve the sustainable food security of the family.
\end{abstract}

Key words: food security, social capital, sustainable, and development.

270 | Suandi. Modal Sosial dan Pembangunan Ketahanan Pangan ... 


\section{PENDAHULUAN}

Pangan merupakan kebutuhan dasar yang paling esensial bagi manusia untuk mempertahankan hidup dan kehidupan. Pangan sebagai sumber zat gizi (karbohidrat, lemak, protein, vitamin, mineral dan air ) menjadi landasan utama manusia untuk mencapai kesehatan dan kesejahteraan sepanjang siklus kehidupan. Dengan demikian, untuk mencapai kondisi tersebut diperlukan suatu pengelolaan terhadap pangan atau yang disebut dengan istilah ketahanan pangan. Ketahanan pangan merupakan kondisi tersedianya pangan yang memenuhi kebutuhan setiap orang setiap saat untuk dapat hidup sehat, aktif dan produktif. Makna yang terkandung dalam ketahanan pangan mencakup dimensi fisik (ketersediaan), ekonomi (daya beli), gizi (pemenuhan kebutuhan gizi individu) nilai budaya dan religius, keamanan pangan (kesehatan), dan waktu (tersedia secara berkesinambungan). Setiap rumahtangga atau individu untuk dapat mengakses pangan pada setiap waktu untuk keperluan hidup yang sehat dengan persyaratan penerimaan pangan sesuai dengan nilai atau budaya setempat (Word Food Summit: Anonim, 1996). Dengan arti kata, ketahanan pangan rumahtangga disamping faktor ketersediaan dan daya beli juga ditentukan oleh faktor akses pangan itu sendiri baik diperoleh secara langsung maupun melalui jaringan lainnya. Tahan berarti terpenuhinya pasokan pangan dan terjaminnya akses pangan sesuai kebutuhan bagi seluruh masyarakat dengan mengandalkan produksi dalam negeri dan kemampuan daya beli masyarakat sendiri.

Salah satu kebijakan pembangunan ekonomi Indonesia dalam Pola Dasar Pembangunan Tahun 2005-2009 adalah pengembangan sistem ketahanan Pangan yang berbasis kepada keragaman sumberdaya bahan pangan, kelembagaan dan budaya lokal. Kemudian, menjamin tersedianya pangan dan nutrisi dalam jumlah dan mutu yang dibutuhkan pada tingkat harga yang terjangkau, serta memperhatikan peningkatan produksi dan kesejahteraan penduduk. Dengan arti kata, pembangunan ketahanan pangan memerlukan harmonisasi dan sinergitas antara pembangunan subsistem ketersediaan, aksesibilitas, dan pembangunan subsistem pemanfaatan pangan dan gizi.

Seiring dengan otonomi daerah maka sangat penting bagi setiap daerah (provinsi dan kabupaten/kota) untuk menyusun perencanaan pembangunan ketahanan pangan guna mewujudkan ketahanan pangan berkelanjutan yang dapat berdampak langsung terutama pada kelompok masyarakat miskin, seperti diamanatkan pada Peraturan Pemerintah (Perpres) No 7 Tahun 2005 tentang Rencana Pembangunan Jangka Menengah diantaranya menyangkut tentang terpenuhinya kecukupan pangan yang bermutu dan terjangkau bagi masyarakat miskin, dan model ini dapat dijalankan secara efektif dan produktif yaitu melalui pemanfaatan modal sosial masyarakat. Mengingat modal sosial merupakan sumberdaya terpenting dalam kehidupan masyarakat karena modal ini merupakan jaringan/hubungan keluarga terhadap dunia luar baik bersifat formal maupun informal untuk memecahkan berbagai persoalan yang ada di masyarakat termasuk masalah kebutuhan pangan keluarga. Dengan arti kata, 
modal sosial merupakan bentuk jaringan kerja sosial dan ekonomi di masyarakat yang terjadi antar individu dan kelompok yang bermanfaat dan menguntungkan (Suandi, dan Zulkarnain, 2009).

Tujuan umum penelitian ini adalah untuk mengidentifikasi dan memformulasikan berbagai faktor ketahanan pangan rumahtangga dan modal sosial masyarakat yang ada di daerah perdesaan Kabupaten Kerinci. Secara khusus, penelitian ini bertujuan (1) Mengidentifikasi berbagai karakteristik ketahanan pangan ruamhatangga di daerah perdesaan, (2) Mengidentifikasi dan mengkaji modal sosial yang berkembang di daerah perdesaan, (3) Mengidentifikasi dan mengkaji ketahanan pangan berkelanjutan di daerah penelitian, dan (4) Mengkaji keterkaitan modal sosial terhadap ketahanan pangan berkelanjutan pada berbagai kelompok masyarakat.

\section{METODE PENELITIAN}

Desain penelitian adalah cross sectional. Penelitian dilakukan di Kabupaten Kerinci Provinsi Jambi. Waktu pengumpulan data penelitian dan penulisan laporan selama 8 (delapan) bulan kalender. Variabel penelitian: (1) ketahanan pangan keluarga (ketersediaan: sumberdaya dan produksi, akses pangan: produksi, pendapatan dan konsumsi, dan pemanfaatan pangan dan gizi: konsumsi dan status gizi), (2) Modal sosial (asosiasi lokal dan karakter masyarakat). Asosiasi lokal (jumlah asosiasi yang diikuti, tingkat partisipasi dalam asosiasi, dan manfaat asosiasi). Karakter masyarakat (tingkat keterpercayaan, solidaritas, dan semangat kerja), dan (3) parameter keberlanjutan pengelolaan ketahanan pangan (keberlanjutan ekologi, sosial ekonomi, dan keberlanjutan sosio-demografi). Data penelitian bersumber dari data primer dan sekunder yang diambil dengan cara observasi, wawancara langsung, indepth interview dan Focus Group Discussion (FGD) pada 165 rumahtangga sampel yang diambil secara berturut-turut dengan cara cluster, purposive, dan simple random sampling. Untuk menjawab tujuan penelitian terutama keterkaitan modal sosial terhadap ketahanan pangan berkelanjutan secara kausalitas dan komprehensif di analisis melalui model Structural Equation Model (SEM) dengan program Linear Structural Relationship (LISREL) versi-8.7. Tingkat validitas penelitian salah satunya ditentukan oleh reliabilitas instrumen atau tingkat konsistensi antar konstrak variabel penelitian.

\section{HASIL DAN PEMBAHASAN}

\section{Ketahanan Pangan Keluarga}

Ketahanan pangan merupakan kondisi tersedianya pangan yang memenuhi kebutuhan setiap orang setiap saat untuk dapat hidup sehat, aktif dan produktif. Makna yang terkandung dalam ketahanan pangan mencakup 
dimensi fisik (ketersediaan), ekonomi (daya beli), gizi (pemenuhan kebutuhan gizi individu) nilai budaya dan religius, keamanan pangan (kesehatan), dan waktu (tersedia secara berkesinambungan) (Martianto dan Hardinsyah: Hardinsyah, 2007). Setiap rumahtangga atau individu untuk dapat mengakses pangan pada setiap waktu untuk keperluan hidup yang sehat dengan persyaratan penerimaan pangan sesuai dengan nilai atau budaya setempat (Word Food Summit: Hardinsyah, 2007). Seperti terlihat pada Tabel 1, bahwa ratarata tingkat ketahanan pangan rumahtangga di daerah penelitian tergolong kuat. Dari 165 responden yang diwawancarai, terdapat sebanyak 70 persen lebih menyatakan bahwa mereka tergolong pada kelompok rumahtangga yang tahan dan sangat tahan dalam pengelolaan pangan rumahtangga. Kemudian, setelah dilakukan pembilahan dari ketiga subsistem, ternyata pengelolaan pangan yang paling kuat terdapat pada pengelolaan susbsistem pemanfaatan pangan yaitu mencapai 73 persen lebih, sedangkan pengelolaan pangan pada subsistem aksesibilitas dan subsistem ketersediaan masing-masing adalah sebesar 72 dan 70 persen. Perlu dicatat, ketersediaan pangan yang dimiliki oleh rumahtangga di daerah penelitian adalah ketersediaan pangan secara fisik yang berasal dari produksi sendiri dan stok pangan sebelumnya, sedangkan import tidak dihitung dalam pengukuran ketersediaan pangan di daerah penelitian.

Tabel 1. Distribusi Responden Berdasarkan Tingkat Ketahanan Pangan Rumah Tangga, Tahun 2012

\begin{tabular}{llrc}
\hline \multirow{2}{*}{ No } & \multicolumn{1}{c}{$\begin{array}{c}\text { Tingkat Ketahanan Pangan } \\
\text { Rumah Tangga }\end{array}$} & Frekuensi & Persentase \\
\hline 1 & Tidak Tahan & 6 & 3,6 \\
2 & Kurang Tahan & 41 & 24,9 \\
3 & Tahan & 94 & 57,0 \\
4 & Sangat Tahan & 24 & 14,5 \\
\hline \multicolumn{1}{c}{ Total } & 165 & 100,0 \\
\hline
\end{tabular}

\section{Modal Sosial}

Modal sosial merupakan bentuk jaringan kerja sosial dan ekonomi di masyarakat yang terjadi antar individu dan kelompok baik formal maupun informal yang bermanfaat dan menguntungkan. Modal sosial dikategorikan melalui dua dimensi yang saling berhubungan (interrelated), yakni: dimensi struktural, dan dimensi karakter ${ }^{1}$. Dimensi struktural diukur dalam bentuk kelompok dan organisasi (asosiasi lokal). Tinggi rendah kontribusi asosiasi lokal terhadap kesejahteraan keluarga diukur secara komposit dari dimensi (a) jumlah

1 Konsep ini mengacu pada konsep yang dikembangkan oleh Bourdieu (1986), Coleman (1988), dan Putnam, Leonardi, dan Nanetti (1993), Grootaert (1997), Woolcock (1998), Fukuyama (1999), Uphoff (1999) (Dasgupta P., 2000:218), dan Flores dan Fernando (2003) (disempurnakan). 
asosiasi yang diikuti, (b) tingkat partisipasi dalam asosiasi, dan (c) manfaat asosiasi dengan nilai sebagai berikut: (1) sangat rendah, (2) rendah, (3) tinggi, dan (4) sangat tinggi, sedangkan dimensi karakter diukur dari nilai komposit: (a) tingkat keterpercayaan, (b) solidaritas, dan (c) semangat kerja dengan nilai: (1) sangat rendah, (2) rendah, (3) tinggi, dan (4) sangat tinggi.

Hasil pengamatan lapangan diperoleh bahwa jumlah asosiasi lokal yang diikuti keluarga contoh di daerah penelitian tergolong besar karena lebih dari 65 persen keluarga contoh mengikuti sebanyak tiga atau lebih asosiasi lokal. Dengan semakin banyaknya jumlah asosiasi lokal yang diikuti oleh anggota keluarga contoh diharapkan dapat mendukung atau mempengaruhi tingkat kebersamaan dan solidaritas sesama anggota masyarakat sehingga pada gilirannya akan berdampak terhadap kesejahteraan dan kemajuan desa. Kemudian, pada masa era globalisasi, reformasi dan otonomi daerah, asosiasi lokal yang berkembang di daerah dan diikuti oleh anggota masyarakat akan sangat berperan dalam membendung dan menopang berbagai informasi berupa inovasi baru yang datang dari luar terutama yang berkaitan dengan kehidupan masyarakat dan pembangunan daerah (Tabel 2).

Tabel 2. Distribusi Responden Berdasarkan Asosiasi Lokal Rumah Tangga, Tahun 2012

\begin{tabular}{llcc}
\hline No & \multicolumn{1}{c}{ Tingkat Asosiasi } & Frekuensi & Persentase \\
\hline 1 & Sangat Rendah & 16 & 9,7 \\
2 & Rendah & 26 & 15,8 \\
3 & Tinggi & 63 & 38,2 \\
4 & Sangat Tinggi & 60 & 36,4 \\
\hline \multicolumn{2}{r}{ Total } & 165 & 100,0 \\
\hline
\end{tabular}

Aspek lain dari dimensi modal sosial adalah karakter masyarakat. Karakter seorang individu merupakan "the sum total of the disinguishing qualities of a person" atau sering juga disebut dengan istilah "moral exellence and strength" (Webster: Hastuti, 2006). Lichona (Hastuti, 2006,11) melihat bahwa karakter terdiri dari tiga dimensi yang saling terkait satu sama lainnya, yakni: pengetahuan tentang moral (moral knowing), perasaan tentang moral (moral feeling), dan perilaku bermoral (moral behavior). Artinya, seorang individu yang berkarakter baik apabila individu tersebut dapat mengetahui tentang berbagai kebaikan (knowing the good), menginginkan dan selalu mencintai kebaikan (loving the good), dan selalu melakukan berbagai tindakan yang baik (acting the good). Implementasi dalam kehidupan sehari-hari dan seorang individu yang berkarakter baik dapat dilihat pada pola hidup dan interaksi sosial mereka dengan masyarakat dalam konteks: nilai keterpercayaan, solidaritas dan semangat kerja. Nilai keterpercayaan diukur dari tiga dimensi, yaitu: komitmen terhadap norma yang berlaku, kejujuran, dan tanggung jawab. Solidaritas masyarakat dilihat dari aspek: tingkat ketergantungan antar anggota 
masyarakat, saling bantu membantu, dan aspek kepekaan terhadap kemajuan desa, sedangkan aspek semangat kerja diukur dari disiplin dan keuletan kerja masyarakat.

Hasil temuan lapangan diketahui bahwa lebih dari 75 persen, karakter masyarakat di daerah penelitian tergolong tinggi dan sangat tinggi (Tabel 3). Dari ketiga dimensi karakter masyarakat, dimensi yang paling tinggi terdapat pada tingkat solidaritas masyarakat yaitu mencapai 77 persen lebih. Tinggi rendahnya tingkat solidaritas masyarakat dilihat dari tiga dimensi: ketergantungan satu sama lainnya, saling bantu membantu, dan adanya kepekaan terhadap kemajuan desa. Secara operasional solidaritas masyarakat merupakan frekuensi interaksi antara satu individu dengan individu lainnya yang merujuk pada seberapa jauh individu melakukan kontak-kontak langsung antara satu dengan lainnya. Semakin positif sifat interrelasi diantara anggota masyarakat yang berupa solidaritas, atau semangat kemasyarakatan, semakin besar kecenderungannya untuk saling memperhatikan keinginan masingmasing dalam mencari jalan ke arah saling memberi kepuasan dan kerjasama.

Tabel 3. Distribusi Responden Berdasarkan Karakter Masyarakat, Tahun 2012

\begin{tabular}{llcc}
\hline No & \multicolumn{1}{c}{ Karakter Masyarakat } & Frekuensi & Persentase \\
\hline 1 & Sangat Rendah & 11 & 6,7 \\
2 & Rendah & 26 & 15,8 \\
3 & Tinggi & 66 & 40,0 \\
4 & Sangat Tinggi & 62 & 37,6 \\
\hline \multicolumn{2}{r}{ Total } & 165 & 100,0 \\
\hline
\end{tabular}

Kemudian, hal lain tak kalah menarik terhadap karakter masyarakat yaitu dimensi keterpercayaan. Data menunjukkan bahwa tingkat keterpercayaan masyarakat di daerah penelitian memiliki nilai cukup tinggi yaitu sekitar 75 persen. Relatif tingginya tingkat keterpercayaan masyarakat yang ada di Kabupaten Kerinci sangat terkait dengan pola hubungan individu dalam masyarakat. Pola hubungan atau interaksi individu dalam masyarakat Kerinci yaitu menganut sistem "kalbu." Sistem kalbu adalah interaksi sosial/hubungan sosial masyarakat dalam kelompok atau turunan tertentu yang dibingkai dalam sebuah kedepatian dan lembaga adat dengan satu tujuan. Artinya, satu depati dengan depati yang lain saling kait mengkait dan saling ketergantungan untuk membangun sebuah kelembagaan yang kokoh yang disebut dengan kelembagaan adat. Namun, karakter masyarakat pada dimensi semangat kerja masih tergolong rendah yaitu baru mencapai 56,6 persen.

\section{Ketahanan Pangan Berkelanjutan}

Ketahanan pangan berkelanjutan diketahui bahwa setiap orang dapat mengakses pangan yang cukup (tersedia, terjangkau dan aman) untuk mempertahankan kehidupan yang sehat, produktif, dan tidak dijumpai gizi 
buruk. Pangan dapat diperoleh secara efektif, efisien, dan murah dengan penggunaan sumber daya alam yang sesuai dan berkelanjutan (International Food Policy Research Institute, 2002). Konsep ini sejalan dengan pembangunan berkelanjutan secara global (WCED: Achmad Suryana, 2005). "Pembangunan berkelanjutan ialah pembangunan yang mewujudkan kebutuhan saat ini tanpa mengurangi kemampuan generasi mendatang untuk mewujudkan kebutuhan mereka".

Sejak akhir tahun 1980'an kajian dan diskusi untuk merumuskan konsep pembangunan bekelanjutan yang operasional dan diterima secara universal terus berlanjut dengan berbagai dimensi dan komponen namun bertumpu pada tiga pilar, yaitu: pilar ekonomi, sosial, dan pilar ekologi (Munasinghe: Achmad Suryana, 2005). Dengan perkataan lain, konsep pembangunan berkelanjutan berorientasi pada tiga dimensi keberlanjutan, yaitu: keberlanjutan usaha ekonomi (profit), keberlanjutan kehidupan sosial manusia (people), keberlanjutan ekologi alam (planet), atau pilar Triple-P.

Hasil pengamatan di lapangan, diperoleh bahwa ketahanan pangan berkelanjutan di daerah penelitian cukup tinggi, baik dilihat dari keberlanjutan social ekonomi, ekologi maupun keberlanjutan secara sosio-demografi. Seperti terlihat pada Tabel 4, dimana ketahanan pangan masyarakat di daerah penelitian memiliki nilai keberlanjutan mencapai 70 persen lebih. Tingkat keberlanjutan paling tinggi terdapat pada dimensi keberlanjutan secara ekonomi yaitu mencapai 73 persen, kemudian diikuti keberlanjutan secara ekologi yaitu sebesar 72 persen, sedangkan tingkat keberlanjutan terendah terdapat pada dimensi sosio-demografi yaitu hanya 70 persen.

Tabel 4. Distribusi Responden Berdasarkan Ketahanan Pangan Berkelanjutan, Tahun 2012

\begin{tabular}{llcc}
\hline No & Karakter Masyarakat & Frekuensi & Persentase \\
\hline 1 & Tidak berkelanjutan & 8 & 4,85 \\
2 & Kurang berkelanjutan & 40 & 24,24 \\
3 & Berkelanjutan & 90 & 54,55 \\
4 & Sangat berkelanjutan & 27 & 16,36 \\
\hline \multicolumn{2}{c}{ Total } & 165 & 100,00 \\
\hline
\end{tabular}

\section{Keterkaitan Modal Sosial dengan Ketahanan Pangan Berkelanjutan}

Keterkaitan modal sosial terhadap ketahanan pangan berkelanjutan dianalisis dengan menggunakan model SEM. Melalui model ini dapat diketahui pengaruh atau hubungan antar konstrak secara kausalitas. Sesuai dengan hipotesis, sehingga variabel konstrak terdiri dari tiga variabel laten utama, yakni: Modal Sosial, Ketahanan Pangan, dan kesejahteraan. Dalam analisis, modal sosial dipecah menjadi dua bagian yaitu (1) Asosiasi Lokal (Aslok) dengan loading variabel: (X1) jumlah asosiasi yang diikuti, (X2) tingkat partisipasi, dan (X3) manfaat asosiasi; (2) Karakter Masyarakat (Kmas) dengan loading variabel: (X4) kepercayaan, (X5) solidaritas, dan (X6) semangat kerja; (3) 
Ketahanan Pangan Rumahtangga (KPR) dengan loading variabel: (Y1) ketersediaan pangan, (Y2) aksesibilitas pangan, dan (Y3) konsumsi pangan; (4) Ketahanan pangan berkelanjutan loading variabel: (Y4) keberlanjutan sosial ekonomi, (Y5) keberlanjutan ekologi, dan (Y6) keberlanjutan secara sosiodemografi.

Berdasarkan analisis melalui model SEM dengan program LISREL diperoleh hasil bahwa tingkat validitas konstruk penelitian pengaruh modal sosial dengan ketahanan pangan berkelanjutan di daerah penelitian cukup valid. Artinya, model-model yang disusun dalam rancangan penelitian cocok atau fit dengan data yang dikumpulkan. Kecocokan/kehandalan rancangan penelitian dan data yang dijaring ditandai oleh nilai-nilai alat uji yang digunakan. Nilai hasil pengujian model mendekati dan melebihi dari cut-off value yang dikehendaki pada masing-masing alat uji kecuali nilai RMSEA (Tabel 5).

Tabel 5 Goodness of Fit Index Pengaruh Modal Sosial terhadap Ketahanan Pangan Berkelanjutan, Tahun 2012

\begin{tabular}{llcc}
\hline No & \multicolumn{1}{c}{ Goodness of Fit } & Cut off Value & Data Lapangan \\
\hline 1 & $\begin{array}{l}\mathrm{X}^{2}(\text { Chi }- \text { Square) }=\text { no sign } \\
\text { atau kecil }\end{array}$ & 0,00 & 0,00 \\
2 & $\begin{array}{l}\text { RMSEA (Root Mean Square } \\
\text { Error of Approximation) }\end{array}$ & $\leq 0,08$ & 0,09 \\
3 & GFI (Goodness of Fist Index) & $>0,90$ & 0,94 \\
4 & CFI (Compartive Fit Index) & $>0,94$ & 0,96
\end{tabular}

Sumber: Joreskog \& Sorborn (Freud dan Carnell (2004:104)

Melalui hasil pengujian model ternyata item loadings untuk variabelvariabel laten dalam model juga menunjukkan konsistensi internal (reliabilitas) sangat signifikan . Seperti terlihat pada Gambar 1, variabel laten asosiasi lokal (Aslok) misalnya yang terdiri dari tiga dimensi yakni: jumlah asosiasi, tingkat partisipasi, dan manfaat asosiasi memiliki nilai loading yang cukup signifikan. Melalui model diketahui item loadings (X1) jumlah asosiasi yang diikuti $(\lambda=$ $0,72),(X 2)$ tingkat partisipasi $(\lambda=0,69)$, dan $(X 3)$ manfaat asosiasi $(\lambda=0,68)$. Hal yang sama juga ditunjukkan oleh item loadings pada variabel laten karakter masyarakat dan kesejahteraan keluarga semuanya menunjukkan nilai $(\lambda)$ yang signifikan. Hasil analisis menunjukkan bahwa variabel modal sosial (asosiasi lokal dan karakter masyarakat) baik secara langsung maupun tidak langsung berpengaruh positif sangat nyata dan signifikan terhadap ketahanan pangan berkelanjutan dengan nilai gamma masing-masing adalah 4,25 dan 3,76. Hal ini membuktikan hipotesis yang dibangun sebelumnya bahwa modal sosial dalam hal ini asosiasi lokal dan karakter masyarakat secara kausalitas dapat mempengaruhi tingkat ketahanan pangan berkelanjutan. Artinya, semakin tinggi dan beragam tingkat modal sosial yang dimiliki oleh masyarakat maka 
semakin baik pula tingkat ketahanan pangan dan pada gilirannya dapat mendukung ketahanan pangan berkelanjutan.

Berkenaan dengan peran modal sosial terhadap pembangunan ketahanan pangan berkelanjutan di daerah penelitian melalui model SEM dan didukung oleh hasil analisis deskriptif tentang manfaat dan akses modal sosial terhadap kebutuhan keluarga menunjukkan bahwa modal sosial berupa jumlah asosiasi, tingkat partisipasi serta kegunaan atau manfaat asosiasi bagi masyarakat sangat berpengaruh terhadap kebutuhan mereka sehari-hari. Modal sosial yang paling dirasakan bermanfaat oleh masyarakat adalah asosiasi yang bergerak di bidang produksi pangan yaitu mencapai 68 persen. Hasil penelitian menunjukkan bahwa asosiasi yang bergerak di bidang produksi pangan ini terdiri dari tiga jenis asosiasi yang berkembang di masyarakat, yakni: asosiasi Kredit Usahatani Tani (KUT), Kelompok Perkumpulan Petani Pemakai Air (KP3A) dan asosiasi Kelembagaan Adat. Asosiasi KUT misalnya adalah asosiasi yang disponsori oleh pemerintah yang bergerak di bidang pertanian dengan kegiatan: bantuan bibit (tanaman, ternak dan ikan) dan bantuan lainnya, KP3A adalah asosiasi desa yang berkembang di masyarakat yaitu kelompok pengelola air irigasi yang digunakan untuk pengairan padi sawah, sedangkan Asosiasi Kelembagaan Adat berperan pengaturan pembangunan dimasyarakat, seperti pembagian aset dan kekayaan pada setiap "kalbu", dan berperan dalam peruntukan dan pergeliran lahan usaha secara berkesinambungan dan berkelanjutan setiap periode musim tanam.

Sesuai dengan kondisi alam dan mata pencaharian utama masyarakat setempat (usahatani padi sawah), KP3A ini berkembang dengan pesat dan banyak kelompok KP3A dijumpai dalam berbagai kelompok kalbu pada masing-masing desa di daerah penelitian. Kelompok ini memegang peranan penting dalam meningkatkan pendapatan masyarakat khususnya produksi usahatani dan produktivitas kerja karena KP3A disamping berperan dalam penyaluran air irigasi juga dapat mengatasi atau membantu dalam penghematan waktu kerja petani. Kondisi ini di dukung budaya yang dianut di daerah penelitian dalam sistem pengelolaan usahatani padi sawah yang disebut sistem "kalbu." Sistem kalbu ini sangat memudahkan dalam membangun kerja bersama. Keakraban dan latar belakang budaya yang sama menguntungkan dalam pemanfaatan fasilitas bersama karena memiliki tingkat emosional yang tinggi untuk kepentingan bersama. Kahkoren (Grootaert: Suandi, 2009) mencontohkan pengelolaan bendungan irigasi di Bangladesh mirip dengan sistem kalbu yang ada di masyarakat kerinci. Ia membuktikan semangat kerjasama bagi kelompok yang berasal dari etnis danbudaya yang sama sangat menguntungkan dalam pengelolaan bendungan irigasi terutama semangat kerjasama.

Hasil temuan lainnya yaitu pengaruh adanya kelompok atau modal sosial lain yang berkembang di daerah penelitian yaitu kelompok "unco". Kelompok "unco" adalah sejenis modal sosial yang sifatnya adalah kegiatan gotong royong namun memiliki nilai ekonomi. Artinya, kegiatan kelompok ini adalah kegiatan 
bersama diantara kelompok "kalbu" dalam masyarakat dengan motif ekonomi. Setiap ada kegiatan "unco", hasil pendapatan kerja diperuntukkan keperluan organisasi atau kelompok bukan individu. Namun, jumlah penghasilan setiap kegiatan kelompok ini cukup beragam dari setiap kelompok karena tergantung dari jumlah keanggotaan, frekuensi kerja, dan keperluan dari setiap kelompok tersebut. Hasil wawancara mendalam dengan tokoh adat di daerah penelitian menunjukkan bahwa rata-rata penghasilan kerja kelompok ini sebesar Rp.4.000.000,-. Penghasilan tersebut diperoleh dari kegiatan kelompok dengan anggota sebanyak 20 orang, rata-rata upah setiap orang sebesar Rp.40.000,- dan dilakukan sebanyak 5 kali selama tahun 2011. Hasil kegiatan kelompok "unco" ini pada tahun tersebut digunakan untuk keperluan pembangunan Fasilitas Umum terutama bidang produksi.

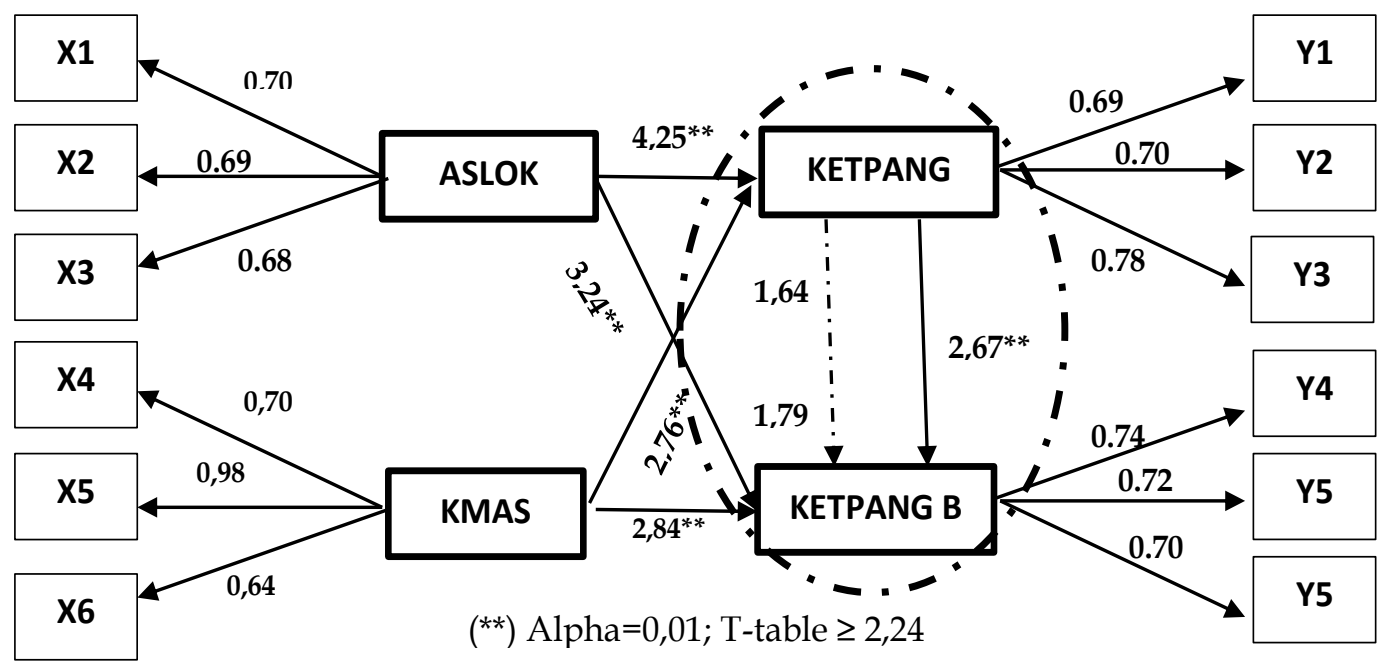

Keterangan: ASLOK (Asosiasi Lokal): X1 = Jumlah asosiasi yang diikuti, X2=Tingkat partisipasi, X3=Manfaat Asosiasi, KMAS (Karakter Masyarakat): X4= Tingkat kepercayaan, X5=Solidaritas, X6= Semangat kerja; KETPANG (Ketahanan Pangan): $\mathrm{Y} 1=$ Ketersediaan pangan, $\mathrm{Y} 2=A \mathrm{kses}$ pangan, Y3=Konsumsi pangan, KETPANG - B (Ketahanan Pangan Berkelanjutan): Y4=Keberlanjutan sosial ekonomi, Y5=Keberlanjutan ekologi, dan Y6= keberlanjutan Sosio-demografi.

Gambar 1 Hubungan Struktural Antara Faktor Modal Sosial dengan Ketahanan Pangan Berkelanjutan

Hasil penelitian menunjukkan bahwa modal sosial dapat berperan dalam meningkatkan ketahanan pangan berkelanjutan masyarakat baik dilihat dari aspek peningkatan keberlanjutan dalam bidang pendidikan (peningkatan 
keteramilan), usaha ekonomi, konservasi alam (penggunaan lahan berkelanjutan), pengembangan karakter masyarakat (solidaritas, kerjasama, gotong royong), maupun peningkatan jaringan sosial yang berkembang dimasyarakat.

\section{SIMPULAN DAN SARAN}

\section{Simpulan}

1. Rata-rata tingkat ketahanan pangan rumahtangga di daerah penelitian tergolong kuat. Terdapat sebanyak 70 persen lebih menyatakan bahwa mereka tergolong pada kelompok rumahtangga yang tahan dan sangat tahan dalam pengelolaan pangan rumahtangga. Pengelolaan pangan yang paling kuat terdapat pada pengelolaan susbsistem pemanfaatan pangan yaitu mencapai 73 persen lebih, sedangkan pengelolaan pangan pada subsistem aksesibilitas dan subsistem ketersediaan masing-masing adalah sebesar 72 dan 70 persen. Responden di daerah penelitian memiliki tingkat stabilitas pangan cukup tinggi, hampir sebagian besar responden memiliki ketersediaan pangan terutama beras selama lebih kurang 10 bulan kalender atau sekitar 300 hari. Artinya, hampir setiap hari rumahtangga responden di daerah penelitian selalu tersedia pangan pokok (beras).

2. Modal sosial yang terdapat di daerah penelitian dan dimiliki masyarakat tergolong tinggi baik dilihat dari tingkat asosiasi lokal maupun dari aspek karakter masyarkat. Asosiasi lokal yang dimiliki masyarakat di daerah penelitian cukup bervariatif baik dilihat dari jumlah asosiasi yang diikuti, partisipasi maupun manfaat dari asosiasi lokal itu sendiri dan lebih dari 65 persen. Hal ini mengindikasikan bahwa kepemilikan modal sosial masyarakat di daerah penelitian cukup penting.

3. Ketahanan pangan berkelanjutan di daerah penelitian cukup tinggi, baik dilihat dari keberlanjutan sosial ekonomi, ekologi maupun keberlanjutan secara sosio-demografi. Tingkat keberlanjutan paling tinggi terdapat pada dimensi keberlanjutan secara ekonomi yaitu mencapai 73 persen, kemudian diikuti keberlanjutan secara ekologi yaitu sebesar 72 persen, sedangkan tingkat keberlanjutan terendah terdapat pada dimensi sosio-demografi yaitu hanya 70 persen.

4. Modal sosial (asosiasi lokal dan karakter masyarakat) baik secara langsung maupun tidak langsung berpengaruh positif sangat nyata terhadap ketahanan pangan berkelanjutan. Artinya, semakin tinggi tingkat modal sosial yang dimiliki oleh masyarakat maka semakin baik pula tingkat ketahanan pangan berkelanjutan dan pada gilirannya dapat mengentaskan keluarga dari kemiskinan. Peran modal sosial terhadap ketahanan pangan berkelanjutan di daerah penelitian terjadi melalui sharing informasi di antara anggota kelompok khususnya informasi tentang pangan dan kebutuhannya, sistem kerja bersama atau gotong royong (collective action) baik untuk kegiatan produktif maupun kegiatan sosial untuk mengakses 
pangan, dan pengambilan keputusan bersama (musyawarah). Bentuk lain, yaitu melalui: interaksi sosial (bonding, bridging dan linking). Artinya, semakin tinggi tingkat intensitas anggota keluarga dalam berinteraksi sosial maka ketahanan pangan berkelanjutan masyarakat semakin kuat.

\section{Saran}

1. Dalam mengambil kebijakan tentang ketahanan pangan di wilayah perdesaan perlu mempertimbangkan indikator "modal sosial" sebagai variabel penentu confounding factors).

2. Penguatan modal sosial sangat tepat dalam pemberdayaan keluarga perdesaan untuk meningkatkan ketahanan pangan dan kesejahteraan keluarga.

\section{DAFTAR PUSTAKA}

Anonim, 1996. Rome Declaration on World Food Security. Word Food Summit 1317 November 1996 Rome Italy. Food and Agriculture Organization of the United Nations.

, 2002. Reaching Sustainable Food Security for All by 2020. USA: International Food Policy Research Institute

Dasgupta F, dan I, Serageldin. 2000. Social Capital: A Multifaceted Perspective. The World Bank. Washington: D.C. ISBN 0-8213-4562-1.

Hardinsyah, 2007. Inovasi Gizi dan Pengembangan Modal Sosial. Orasi Ilmiah Guru Besar Tetap Ilmu Gizi Fakultas Ekologi Manusia Institut Pertanian Bogor. Bogor: IPB, Bogor.

Hastuti, Dwi. 2006. Analisis Pengaruh Model Pendidikan Prasekolah pada Pembentukan Anak Sehat, Cerdas dan Berkarakter Secara Berkelanjutan. Disertasi. Bogor: Sekolah Pascasarjana Institut Pertanian Bogor.

Suandi, 2009. Kajian Modal Sosial dan Kesejahteraan Ekonomi Keluarga Petani di Daerah Perdesaan Provinsi Jambi. Laporan Penelitian. Jambi: Lembaga Penelitian Universitas Jambi

Suandi, dan Zulkarnain, 2009. Strategi Pengelolaan Ketahanan Pangan Berkelanjutan di Provinsi Jambi Berdasarkan Agroekologi Wilayah. Laporan Penelitian. Jambi: Lembaga Penelitian Universitas Jambi.

Suryana, Achmad. 2005. Pembangunan Pertanian Berkelanjutan Andalan Pembangunan Nasional. Solo: Makalah Seminar "Sistem Pertanian Berkelanjutan untuk Mendukung Pembangunan Nasional", tanggal 15 Pebruari 2005 di Universitas Sebelas Maret Solo. 

